\title{
Inspecting the Impact of Various Factors Influencing Employee Attrition in Hotel Industry
}

\author{
R. George Leslie Davidson ${ }^{1}$, Dr. G. Brindha ${ }^{2}$ \\ \{georgelesliephd@gmail.com ${ }^{1}$, bkk28@yahoo.co.in ${ }^{2}$ \} \\ Research Scholar, Bharath Institute of Higher Education and research, Chennai. ${ }^{1}$, \\ Professor \& Head, Faculty of Management studies, Dr. M.G.R Educational and Research Institute, \\ Chennai. $^{2}$
}

\begin{abstract}
The study aims to investigate the important reason behind the employee attrition in Star Category Hotels within Tamilnadu with respect to gender and job designation. The current study adopted descriptive research design. The data was collected from 419 samples using structured questionnaire online. For the study, 12 Star category hotels were considered, from which samples were taken through a convenience sampling technique. From the analysis performed, it can be well understood that there no significant difference in opinion among respondents with respect to gender and various Job positions. But using the rank analysis using mean score it can be clearly understood that salary, incentive and benefits are an important reason for the male employee attrition while Work-life balance is the important reason behind the female employee attrition. With respect to job position top-level employees, it is the work-life balance that is causing employee attrition, while for lower-level employees it is salary, incentives and benefits. But for the middle-level employees, it is better employment opportunities in other Star category hotels.
\end{abstract}

Keywords: Employee Attrition, Monetary Benefits, Work-Life Balance, Nature of Work and Better Employment Opportunity.

\section{Introduction}

Hospitality industry leaders can better implement policies and strategies that increase organizational competitiveness and profitability if they understand the factors that significantly affect revenue ratios among employees. To mention a few of these factors include inadequate employee compensation, layoffs, low motivation, job dissatisfaction, and unfavourable work environment.Human resources are the most important and valuable asset of a company. Nevertheless, it is seen as a cost hub by most companies. Employees play an important role in the industry because of everyone. Resources are lost when workers are not used properly and efficiently. A tradition can be created by creating and breaking a system. The success of a company today depends on the efficiency and reliability of human resources to compete in a highly competitive and diverse business world. Recruiting and retaining existing employees is a very difficult issue for every company. Management employees leave a company, it leads to serious problems for the company. Attrition generally increases as a result of business dissatisfaction, low pay, poor working conditions, lack of motivation, poor relationships with colleagues and supervisors, employee dissatisfaction and many more. The 
income ratio reveals that something is wrong with a company's health and the environment in terms of salary, working conditions, industrial relationships, and workplace health services.

Retaining employees is an issue in the business world. This has a huge impact on a company's competitiveness. The arrival of workers in a company causes chronic problems. Workers have recognized the effects of employee income over the past few years. While a company's productivity is not good for growth and development, high commitment ratios indicate instability and workflow inconsistency. Many companies are facing unpredictable costs, manufacturing and job disruptions, recruitment costs, hiring costs, learning and growth. Such issues raise the question of why the car industry is characteristic.

Attrition rate $(\%)=$ Number of employees who resigned per month / (Total number of employees at the beginning of the month + Number of employees who resigned during the month-Number of employees who resigned) $x$ 100. The industry has become quieter. Are coming. Employee earnings or employee attrition are identified as the rate of change of employees in a company over some time. In its broadest sense, the rating ratio estimates the number of people or items leaving a group at a given time. This is one of the two primary factors determining the consistent position of customers who support a business."

\section{Review of Literature}

Milind\&Peshave in this paper explored the details of increasing rates with employee attrition. Reactions are graphically described and analyzed using simple percentages. The results of his research indicate that the main factors affecting the level of inflation in hotels are long working hours and low wages that greatly affect the satisfaction and reputation of hotel customers. Although the hotel industry is concerned about the growing rate and various policies have been formulated to control it, this issue has not been adequately addressed this is inturn leading to employee attrition (Milind A. Peshave, 2015). In these challenging and uncertain times, businesses, executives and leaders face a serious challenge to retain talented employees and reduce revenue. HR managers are eager to hear that workers are leaving their company during this period of cut-throat competition. The demand for hours is to have employees who want to change constantly. This research aims to study the history of Indian wage rates and the factors contributing to the rise in the wage rates of Indian companies. This work attracts secondary information collected from magazines, journals and the Internet (Farkiya, 2016). Of all the workplace challenges, changing external conditions is one of the major issues in the current situation of employee income. With the resignations, deaths and pensions, there is said to be a gradual decline in the number of workers. If for any reason a company is left with a well-trained and well-adjusted worker, there is a vacuum in a company that creates a clear position. It is very difficult to fill the gap for an employee member in human resources. Research helps to understand how turnover occurs. It helps to find explanations for retaining employees and why managers are confronted with retaining employees (Guru Vignesh. S, 2018). 


\section{Objectives of the Study}

The study aims to investigate the important reason behind the employee attrition in Star Category Hotels within Tamilnadu with respect to gender and job designation.

\section{Research Methodology}

For the study,the descriptive research design was adopted. The data was collected from 419 samples using structured questionnaire online. For the study, 12 Star category hotels were considered, from which samples were taken through a convenience sampling technique.

\section{Analysis \& Interpretation}

\section{Causes for Employee attrition with respect to Gender}

As the dependent data type [Causes for Employee Attrition] is metric and independent data type [Gender] being categorical with two option, therefore,Independent Sample T-test was used to identify the whether there is a significant difference in opinion.

Null Hypothesis: There is no significant difference in opinion between male and female for the cause of Employee attrition.

Table No. 1:Causes for Employee attrition with respect to Gender

\begin{tabular}{|c|c|c|c|c|c|c|}
\hline & & \multicolumn{2}{|c|}{$\begin{array}{l}\text { Levene's Test for } \\
\text { Equality of Variances }\end{array}$} & \multicolumn{3}{|c|}{ t-test for Equality of Means } \\
\hline & & $\mathrm{F}$ & Sig. & $\mathrm{t}$ & df & $\begin{array}{l}\text { Sig. (2- } \\
\text { tailed) }\end{array}$ \\
\hline \multirow[t]{2}{*}{$\begin{array}{l}\text { Salary, Incentives } \\
\text { \& Benefits }\end{array}$} & $\begin{array}{l}\text { Equal } \\
\text { variances } \\
\text { assumed } \\
\end{array}$ & .0827 & .7738 & .5906 & 418.0000 & .5551 \\
\hline & $\begin{array}{l}\text { Equal } \\
\text { variances not } \\
\text { assumed }\end{array}$ & & & .5914 & 415.5233 & .5546 \\
\hline \multirow[t]{2}{*}{$\begin{array}{l}\text { Work-Life } \\
\text { Balance }\end{array}$} & $\begin{array}{l}\text { Equal } \\
\text { variances } \\
\text { assumed } \\
\end{array}$ & 1.1677 & .2805 & -1.5203 & 418.0000 & .1292 \\
\hline & $\begin{array}{ll}\text { Equal } & \\
\text { variances not } \\
\text { assumed }\end{array}$ & & & -1.5225 & 415.4719 & .1286 \\
\hline \multirow[t]{2}{*}{ Nature of Work } & $\begin{array}{l}\text { Equal } \\
\text { variances } \\
\text { assumed } \\
\end{array}$ & .0015 & .9691 & -.7902 & 418.0000 & .4299 \\
\hline & $\begin{array}{ll}\text { Equal } & \\
\text { variances not } \\
\text { assumed }\end{array}$ & & & -.7904 & 413.9888 & .4297 \\
\hline
\end{tabular}




\begin{tabular}{|l|l|l|l|l|l|l|}
\hline $\begin{array}{l}\text { Better } \\
\text { Employment } \\
\text { Opportunity }\end{array}$ & $\begin{array}{l}\text { Equal } \\
\text { variances } \\
\text { assumed }\end{array}$ & .7847 & .3762 & .0435 & 418.0000 & .9653 \\
\cline { 2 - 6 } & $\begin{array}{l}\text { Equal } \\
\text { variances not } \\
\text { assumed }\end{array}$ & & & .0436 & 416.7767 & .9653 \\
\hline
\end{tabular}

Source: (Primary data)

The estimated significance value is greater than 0.05 for all the variables. Meaning the Null hypothesis is accepted i.e. there is no significant difference in opinion for the causes for employee attrition between male and female respondents.

The researcher had found no significant difference in opinion. Hereby to have better insight rank analysis was carried out using the mean score.

Table No. 2:Rank Analysis -Causes for Employee attrition with respect to Gender

\begin{tabular}{|l|l|l|l|l|}
\hline & Male & Female \\
\hline & Mean & Rank & Mean & Rank \\
\hline Salary, Incentives \& Benefits & 2.8371 & 1 & 2.7638 & 4 \\
\hline Work Life Balance & 2.7330 & 4 & 2.9246 & 1 \\
\hline Nature of Work & 2.7466 & 3 & 2.8442 & 2 \\
\hline Better Employment Opportunity & 2.8145 & 2 & 2.8090 & 3 \\
\hline
\end{tabular}

Source: (Primary data)

From the rank analysis carried using the mean score, it can be interpreted that, the important reason for male employee attrition are; 1 . Salary, incentive \& benefits, 2. Better Employment Opportunity and 3. Nature of Work. Similarly, the important reason for female employee attrition is; 1. Work-Life Balance, 2.Nature of Work and 3. Better Employment Opportunity.

\section{Causes for Employee attrition with respect to Job Position}

As the dependent data type [Causes for Employee Attrition] is metric and independent data type [Job Position] being categorical with three option, therefore, ANOVA test was used to identify the whether there is a significant difference in opinion.

Null Hypothesis: There is no significant difference in opinion among employees from top, middle and lower level for the cause of Employee attrition.

Table No. 3:Causes for Employee attrition with respect to Job Position

\begin{tabular}{|l|l|l|l|l|l|l|}
\hline \multicolumn{2}{|l|}{ ANOVA } & $\begin{array}{l}\text { Sum of } \\
\text { Squares }\end{array}$ & df & $\begin{array}{l}\text { Mean } \\
\text { Square }\end{array}$ & F & Sig. \\
\hline $\begin{array}{l}\text { Salary, Incentives } \\
\text { Benefits }\end{array}$ & $\begin{array}{l}\text { Between } \\
\text { Groups }\end{array}$ & 1.9913 & 3 & 0.6638 & 0.4105 & 0.7455 \\
\cline { 2 - 8 } & Within Groups & 672.6063 & 416 & 1.6168 & & \\
\cline { 2 - 8 } & Total & 674.5976 & 419 & & & \\
\hline Work-Life Balance & $\begin{array}{l}\text { Between } \\
\text { Groups }\end{array}$ & 9.1633 & 3 & 3.0544 & 1.8420 & 0.1389 \\
\cline { 2 - 8 } & Within Groups & 689.7986 & 416 & 1.6582 & & \\
\cline { 2 - 8 } & Total & 698.9619 & 419 & & & \\
\hline
\end{tabular}




\begin{tabular}{|l|l|l|l|l|l|l|}
\hline Nature of Work & $\begin{array}{l}\text { Between } \\
\text { Groups }\end{array}$ & 10.3748 & 3 & 3.4583 & 2.1844 & 0.0893 \\
\cline { 2 - 7 } & Within Groups & 658.6038 & 416 & 1.5832 & & \\
\cline { 2 - 8 } & Total & 668.9786 & 419 & & & \\
\hline $\begin{array}{l}\text { Better } \\
\text { EmploymentOpportunity }\end{array}$ & $\begin{array}{l}\text { Between } \\
\text { Groups }\end{array}$ & 1.7509 & 3 & 0.5836 & 0.3558 & 0.7850 \\
\cline { 2 - 8 } & Within Groups & 682.3896 & 416 & 1.6404 & & \\
\cline { 2 - 8 } & Total & 684.1405 & 419 & & & \\
\hline
\end{tabular}

Source: (Primary data)

The estimated significance value is greater than 0.05 for all the variables. Meaning the Null hypothesis is accepted i.e. there is no significant difference in opinion for the causes for employee attrition among respondents belonging to the top level, middle level and lower-level position.

The researcher had found no significant difference in opinion. Hereby to have better insight rank analysis was carried out using the mean score.

Table No. 2:Rank Analysis -Causes for Employee attrition with respect to Job Position

\begin{tabular}{|l|l|l|l|l|l|l|}
\hline & \multicolumn{2}{|l|}{ Top Level } & \multicolumn{2}{l|}{ Middle Level } & \multicolumn{2}{l|}{ Lowe Level } \\
\hline & Mean & Rank & Mean & Rank & Mean & Rank \\
\hline Salary, Incentives \& Benefits & 2.7656 & 3 & 2.7293 & 4 & 2.8963 & 1 \\
\hline Work Life Balance & 3.1719 & 1 & 2.7669 & 2 & 2.7630 & 4 \\
\hline Nature of Work & 3.0938 & 2 & 2.7444 & 3 & 2.8370 & 2 \\
\hline Better Employment Opportunity & 2.7031 & 4 & 2.8872 & 1 & 2.8222 & 3 \\
\hline
\end{tabular}

Source: (Primary data)

From the rank analysis carried using the mean score, it can be interpreted that, the important reason for Top-level employee attrition are; 1. Work-Life Balance, 2.Nature of Work and 3.Salary, Incentives \& Benefits. Similarly, the important reason for middle-level employee attrition is; 1. Better Employment Opportunity, 2. Work-Life Balance and 3.Nature of Work. Similarly, the important reason for lower-level employee attrition is; 1. Salary, Incentives \& Benefits, 2.Nature of Work and 3. Better Employment Opportunity.

\section{Findings \& Discussion}

From the analysis performed with 419 samples, it can be well understood that there no significant difference in opinion among respondents with respect to gender and various Job positions. But using the rank analysis using mean score it can be clearly understood that salary, incentive and benefits are an important reason for the male employee attrition while Work-life balance is the important reason behind the female employee attrition. Therefore, it is suggested to star category hotels in Tamilnadu to provide fixed and convenient for female employees. Also, frame suitable HR policies for the welfare for female employee family to reduce employee attrition. While for the male employees it is advised to provide better career options along with increased salary, incentive and benefits to reduce employee attrition. With respect to job position top-level employees, it is the work-life balance that is causing employee attrition, while for lower-level employees it is salary, incentives and benefits. But 
for the middle-level employees, it is better employment opportunities in other Star category hotels, hereby it is suggested to hotels to have suitable policies and contract terms to a certain period to reduce employee attrition rate.

\section{Conclusion}

The current study adopted descriptive research design. The data was collected from 419 samples using structured questionnaire online. For the study, 12 Star category hotels were considered, from which samples were taken through a convenience sampling technique. From the analysis performed, it can be well understood that there no significant difference in opinion among respondents concerning gender and various Job positions. But using the rank analysis using mean score it can be clearly understood that salary, incentive and benefits are an important reason for the male employee attrition while Work-life balance is the important reason behind the female employee attrition. With respect to job position top-level employees, it is the work-life balance that is causing employee attrition, while for lower-level employees it is salary, incentives and benefits. But for the middle-level employees, it is better employment opportunities in other Star category hotels.

\section{References}

[1] Farkiya, R. (2016). A Study on Overview of Employee Attrition Rate in India. Indian Journal of Management, 1-15.

[2] Guru Vignesh. S, S. V. (2018). Employee Attrition and Employee Retention-Challenges \& Suggestions. Conference: International Conference On Economic Transformation with Inclusive Growth, 1-22.

[3] Milind A. Peshave, R. G. (2015). Study Of Factors Influencing Increasing Attrition Rate In Hotels Of Pune, Its Impact On The Organization And Measures Undertaken By The Hotels To Curb The Attrition Rate. JOHAR -- Journal of Hospitality Application \& Research, 1-10.

[4] Abdulla, J. D. (2015). Determinants of Job Satisfaction In The UAE: A Case Study of The Dubai Police. Personnel Review, 126-146.

[5] Ahmad, A. R. (2014). Higher Dissatisfaction Higher Turnover in the Hospitality Industry. International Journal of Academic Research in Business and Social Sciences, 45-52.

[6] Bhattacharya, S. a. (2006). Stress and Coping: A Study on Lady Criminal Lawyers of Kolkata City. Indian Psychological Review, 227-234.

[7] Bilgic, R. (1998). The Relationship Between Job Satisfaction And Personal Characteristics of Turkish Workers. The Journal of Psychology, 549-561.

[8] Hashemi, S. J. (2015). Determinant of Employee Job Satisfaction and Role of Male and Female Differences: An Empirical Study at Hotel Industry in Iran. Journal of Hospitality Application and Research, 15-36. 